\title{
Contesting Multiculturalism:
}

Ethno-regionalism and Contending Forms of Nationalism in Late Colonial Nigeria

\author{
By Wale Adebanwi
}

- Accepted for publication in Commonwealth and Comparative Politics (2081) 


\section{Introduction}

Is multiculturalism the most appropriate way to deal with diversity in an emerging but divided (African) nation-state? Is multiculturalism antithetical to nation-building and mutual recognition of equal value among different ethnic-nationalities within African polities? What happens when multiculturalism simultaneously constitutes the basis of political architecture as well as the fundamental problem of political organization in a multi-ethnic state?

I propose in this article to foreground these key questions by examining different approaches to multiculturalism among Nigeria's three core regions in the period of decolonization. I do so because I think that examining these questions are helpful in understanding the unending political instability in contemporary African states caused largely by the unremitting antagonism between the constituent groups. The article explains the historical sociology of the politics of ethno-cultural diversity in Nigeria in relation to the struggle to construct a suitable political architecture for the governing of a vast country, an architecture that was strong enough to respond to as well as manage Nigerian's diversity while ensuring unity. Generally, I suggest that contemporary problems in multi-ethnic postcolonial African states concerning the best approaches to national unity, diversity, party politics, power sharing, etc. are rooted in different visions of multiculturalism as exemplified in the Nigerian case.

Will Kymlicka recently argued that '(i)deas about the legal and political accommodation of ethnic diversity have been in a state of flux around the world for the past 40 years' (Kymlicka, 2012: 1). However, Kymlicka reflects a dominant trend in the literature in the West (see also, Parekh 2002; Philip, 2007; Modood 2007; Sniderma and Hagendoorn 2007; Crowder 2013) in which contemporary multiculturalism is assumed to be a largely Western experience or problem. ${ }^{1}$ Even while admitting that multiculturalism is a phenomenon that has been around for many centuries and that even in contemporary era, '(i)n very few countries can the citizens be said to share the same language, or belong to the same ethnonational group' (Kymlicka 1995: 1; cf. Crowder 2013: 2), thus making multiculturalism 'a normative response to that fact' (Parekh 2006: 6), yet the focus and examples drawn by many scholars from, or based in, the West are almost always from the Euro-American contexts (extending, sometimes to Australia). In this context, multiculturalism, for the most account, is captured either as a phenomenon defined by the social, economic, political and policy responses to increased immigration from the developing world to the West (see Crowder; Modood 2007; Kymlicka 1995, 1998, 2001, 2007, 2012; Taylor; Parekh 2002), or as represented in the challenges faced by minorities (racial, ethnic, religious or gender) in contemporary Western societies (see, among others, Philips 2007) - or both. Perhaps because of its peculiar experience of state racism that survived up the last decade of the $20^{\text {th }}$ century, South Africa is the only country in Africa that has attracted sufficient attention in the extant literature on multiculturalism (see Horowitz, 1991; Soudien 1994; Bekker and Leidé 2003).

Kymlicka (2012: 6, emphasis added), among others, also dates the 'struggle for multiculturalism and minority rights' as having emerged 'in the late 1960s,' as one of the three 'waves' of movements which arose against the backdrop of 'this new assumption of human equality [which] generated a series of political movements designed to contest the lingering presence or enduring effects of older hierarchies.' Contrary to this position, the Nigerian case as evident in several other African countries, including Kenya, (South) Sudan, South Africa, Cameroon, Uganda, DRC, Mauritania, Central African Republic, etc. - shows that the struggle for multicultural diversity in Africa preceded this period, even if the specific language of 
'multiculturalism' was not used at this point. Also, many cases in Africa point to the fact that the struggle for multiculturalism regarding 'the lingering presence or enduring effects of older hierarchies' is not only one in which minority groups are pitched against dominant majority groups. In some cases, such struggles set dominant or marginal majority groups against one another or even marginal majority groups against dominant minority groups.

Against this backdrop, Amy Gutmann's (1993: 171, emphasis added) emphasis added definition of multiculturalism as 'the state of a society or the world containing many cultures that interact in some significant way with each other,' is one of the most useful ways of approaching this phenomenon. However, as the African experience has shown, while multiculturalism is potentially a positive principle in multi-ethnic societies and states, its practices may not necessarily produce beneficial consequences. The uses to which dominant groups, systems or parties put multiculturalism may in fact portend danger for the democratic principles inherent in the idea of multiculturalism. As Asef Bayat (2009: 186) has argued, though multiculturalism 'calls for equal coexistence of different cultures within a national society,' the politics of multiculturalism is paradoxically also steeped in 'the language of separation and antagonism [as well as] cultural superiority and ethnocentrism'

To account for this, it is important to pay attention to the historical context of multiculturalism in understanding its contemporary successes or failures in actually existing societies. Examining particular contexts of multiculturalism also helps to explain what it means in different societies and at different points. Here, I examine the debate between those who imagined multiculturalism as (semi-)separatism (called by all sorts of names including, 'Pakistanisation', 'tribalism', etc.) and those who approached multiculturalism as a critical basis for the survival of a deeply divided and plural society, such as Nigeria. I want to use the 'solutions' provided in the Nigerian experience to reflect on the questions I pose above. I will attempt to do this by reflecting on British colonial legacy in Nigeria, the decolonization-era debates on the best political architecture for a multi-ethnic state, the principles that inform the positions taken, the responses that these positions generated, and how the Nigerian experience speaks to the phenomenon of multiculturalism in general.

\section{The (Post)Colony and the Challenge of Multiculturalism}

In August 2004, over 500 delegates representing different groups, particularly ethnoregional groups, concluded five months of contentious deliberations on the existing divisive political structure and the future of Nigeria. The fundamental crisis of nation-building that provoked the convocation of the National Conference, the fourth of its kind in post-independence Nigeria, as the BBC reported, 'has seen bitter conflicts between [Nigeria's] numerous ethnic, religious and linguistic groups' (Abubakar 2014). Over 600 resolutions were passed with a 10, 335-page report produced and submitted to President Goodluck Jonathan. The Chairman of the National Conference Committee, former Chief Justice Idris Kutigi, reportedly stated that fears expressed in some parts of the country that the conference would lead to the disintegration of the country had been dispelled (ibid).

However, that questions were still been raised about basic issues of national unity fiftyfour years after independence and six decades after the key structural issues regarding unity were assumed to have been resolved at the pre-independence constitutional conferences points to the lingering problems regarding the multicultural nature of Nigeria. Mohammed Haruna, a leading journalist and one of the most vociferous defenders of northern interests and Islam in Nigeria and 
an antagonist of the idea of national conference in Nigeria, told the BBC that "virtually every [post-independence] constitutional conference in this country has come with a hidden agenda by its convener and virtually all of them have come to grief' (ibid, emphasis added). What Haruna describes as 'hidden agenda' is the suspicion among the political elite of core northern region that post-independence national conferences in Nigeria promoted by the southern political elite were designed to limit the influence of the north in the country. Therefore, the region has always been opposed to all post-civil war national conferences and the struggle for 'political restructuring' of the federation championed mainly by southerners. Indeed, it is significant that all the successful (national) constitutional conferences were the ones held in the late colonial period. These conferences determined the fundamental structures of the Nigerian federation. Every other major and successful tinkering with the structure of the federation since independence was done by the military, mostly led by northern soldiers. In fact, the only major change under a non-northern military ruler, that is, General Aguiyi Ironsi, an Igbo (southern) military ruler (among other factors) provoked a counter-coup and led eventually to a civil war. The Ironsi regime had abolished the federal system and replaced it with the unitary system (of provinces).

In the light of the fact that all attempts to fundamentally reshape the Nigerian federation through democratic process has failed, it is important to re-examine the original positions and debates among the three regions and their leaders which continue to largely determine the current attitudes toward multiculturalism in Nigeria.

Diversity or plurality is one of the most important issues constantly raised in, and about, Nigeria. The recognition of the multicultural nature of the country evident in the old anthem ${ }^{2}$ and the national 'aspirations' encoded in it, could as well have served as a reflection of the controversies and contestations over Nigeria's unity and nationalism in the two decades preceding Nigeria's independence. This was especially true as the leaders of the different ethnoregional formations fought hard to ensure the recognition of their different political as well as cultural identities. The Nigerian experience is no surprise, though, given that, as David Theo Goldberg (1994: 7) argues '(m)ulticulturalism and commitments to diversity emerged out of [the] conflictual history of resistance, accommodation, integration, and transformation.' Against this backdrop, a central question that arose in late colonial Nigeria, as reflected in the struggles between those who wanted independent Nigeria to be a federal state and those who favored a unitary state was this: Is multiculturalism a menace? ${ }^{3}$

Indeed, before, and even more so since, the British amalgamated the northern and southern protectorates in 1914 to form Nigeria as a single colony, difference and multiculturalism were largely constructed by important sections of the national political elites, even those who affirmed their own identity, as a menace. The British colonialists no less believed so and practiced this, even while insisting that the fate and fortune of the different ethnic, cultural, and religious groups in Nigeria were tied together. As Sir Abubakar Tafawa Balewa, one of the leaders of the Northern People's Congress (NPC) - who later became Nigeria's first and only Prime Minister - articulated it, since the amalgamation 'the British Government has been trying to make Nigeria into one country'. Balewa saw this as a futile effort because he considered the people who made up the country as 'different in every way, including religion, custom, language and aspirations.' He concluded that 'Nigeria's unity is only a British intention for the country they created...' The differences among the components parts of Nigeria, Balewa submitted, were too deep to make unity possible. 
John N. Paden, biographer of Sir Ahmadu Bello, the late first premier of the Northern Region of Nigeria, recalls an encounter in the mid-1960s between two of the three Nigerian leaders whose attitude to multiculturalism helped to shape Nigeria's future - against the backdrop of the powerful effects of the colonial architecture. Bello and Dr. Nnamdi Azikiwe, the first premier of the Eastern Region of Nigeria and, later, the country's first ceremonial president, are said to have had a meeting in which the latter demanded of Bello, 'Let us forget our differences...' to which Bello reacted, 'No, let us understand our differences. I am a Muslim and northerner. You are a Christian and easterner. By understanding our differences, we can build unity in our country' (Paden 1986: 3, emphasis added).

Even though Bello and Azikiwe did not use specifically the language of multiculturalism in this encounter, their preceding and succeeding statements and actions in Nigeria's history provide further evidence of their different and differing attitudes to cultural diversity among Nigeria's many ethnicities and faiths. If multiculturalism is, at the core, 'a principle [that indicates] respect for the pluralism of cultures' (Sniderman and Hagendoorn 2007: xi), then forgetting differences might connote disregarding the pluralism of cultures, while understanding difference might mean accepting the reality of such plurality, as Bello insisted.

Though Bello had a restrictive approach to multiculturalism - that is, along ethnoregional and religious lines ${ }^{4}$ - the position he and his party, the Northern Peoples' Congress (NPC), canvassed strongly challenged the assimilationist policy officially championed by Azikiwe and his party, the National Congress for Nigerian Citizens (NCNC).

Before Bello and Azikiwe had this encounter, the third of the triumvirate Nigerian nationalist leaders and first Premier of the Western Region, Chief Obafemi Awolowo, had led a frontal debate between his political party, the Action Group, and its supporters against Azikiwe's NCNC and its supporters, on the best structural (political) and constitutional arrangement that could guarantee Nigeria's multicultural realities. The core of this debate revolved around the best political system - federalism or unitarism - that could be adopted by a multi-ethnic state such as Nigeria after independence from Britain. Incidentally, the two sides agreed that the question of Nigeria's multi-ethnic and multi-religious nature was a critical one that ought to be confronted through the political arrangement that would succeed British colonial rule. Azikiwe and the NCNC, for the most part, identified the multicultural nature of Nigeria as a menace or a problem that ought to be transcended, if not solved, through assimilationist, or (politically) centralizing policies, starting with a unitary system of government. In this model, a central government would be supreme while all subnational units would exist by the authority of the central government. On the contrary, Awolowo, and later Bello - both with different inflections argued that Nigeria's multiculturalism should be approached as a strength that ought to be recognized and honored, through decentralizing policies, which would constitute essential building blocks in the struggle for national unity and development.

This debate was not limited to Nigeria. In much of Africa in the late colonial and earlier independence era, multiculturalism was generally regarded as a menace to 'national unity,' 'peace', 'progress' and economic, political and social 'development.' While most modern African states, with the possible exception of Somalia, were created as multi-ethnic states through colonialism, federalist aspirations in most parts of the continent were approached primarily as disuniting, separatist or secessionist. ${ }^{5}$ Attempts at operating federal systems collapsed in many instances, such as the federation of Rhodesia and Nyasaland (when Nyasaland became Malawi at independence), Cameroon (which changed to unitary system in 1972), Kenya 
(where the 'Majinbo' constitution with federal features was changed in favor of unitary system under Kenyatta), and Uganda (where President Milton Obote dropped the asymmetrical relations the center and the provinces in 1955) (see, Elaigwu, 2010). The dominant attitude in African states to federalism has produced different consequences such as the imposition of unitarist form of government, one party state (later one party dominant system), authoritarian rule, silencing of ethnic, religious and cultural minorities, etc. At independence and for much of the first two decades after, most African states attempted to forget their inherent multiculturalism rather than recognize it. In the few cases where a measure of accommodation was given to multiculturalism, extreme centrifugal forces eventually encouraged the victory of centripetal forces. Thus, multiculturalism, in late colonial and early independence eras in Africa, was regarded as a menace to nation-building, national unity, and development. ${ }^{6}$

Despite this, in every country in Africa, the challenges of multiculturalism could not be avoided. However, each country in Africa faced different forms of the specific challenges of multiculturalism and responded in different ways (see, Bekker and Leidé, 2003; Soudien, 1994). This was because, in most cases, different kinds of historical circumstances dictated the nature of the challenges faced and the opportunities and limitations of the responses.

\section{Multiculturalism and Indirect Rule}

I suggest that no robust analysis of multiculturalism in Africa can proceed without understanding the historical context. In the case of Nigeria, in particular, the structuring - as well as epochal - powers of the indirect rule system introduced by the British colonial administration and its consequences in determining the nature of the multiethnic state are critical. The "principle of ruling through the native chiefs' imposed on Nigeria, as its chief architect, Frederick Lugard (1922: 199; see also Kirk-Greene 1969: 70), the first British Governor General of amalgamated Nigeria, described the indirect rule system (or Native Authority System), was one in which 'racial dualism,' as Mahmood Mamdani (1996: 7) famously captures it, was 'anchored in a politically enforced ethnic pluralism.' And because this 'ethnic pluralism' was underlined by 'the contradictory character of ethnicity' (ibid: 8 ), when the bifurcated state created by colonialism was de-racialized in much of Africa, it was not democratized (ibid). Hence, multiculturalism, even though inherently a democratic phenomenon, process and policy has remained more of a (democratic) potential than reality in much of Africa. In most of the countries, struggles (violent and non-violent) to achieve democratic multiculturalism are the rule rather than the exception.

Given that the indirect rule system was a form of 'decentralized despotism' (Mamdani 1996: 52), multiculturalism was produced and entrenched as a technology of rule rather than as a democratic tool for recognizing difference and diversity. The nature of multi-ethnic state which succeeded the colonial state therefore reproduced forms of multiculturalism which were a dimension of power as well as a form of resistance, a part of the problem as well as a part of the solution (Cf. Mamdani 1996: 8; Vaughan 2003: 230) in the African postcolonial state.

From 1900 to 1906, Lugard was the High Commissioner of the British Protectorate of Northern Nigeria where he established the practice of administering the colony through emirs and local chiefs (Sklar 1963: 18). In 1914, he was appointed as the Governor-General of the amalgamated territories (of Northern and Southern Protectorates) called the Colony and Protectorate of Nigeria. While the indirect rule system was most suitable for the Northern Protectorate (largely dominated by the Fulani emirs), and less so for the Western part of the Southern Protectorate (with its monarchical system) and most unsuitable for the Igbo areas of the 
Eastern part of the Southern Protectorate (which composed of acephalous societies), it was nonetheless extended over the whole of colonial Nigeria, thus producing specific forms of struggles for multiculturalism that Nigeria still contends with today.

As reflected in the opinion expressed by Lugard's successor, Sir Hugh Clifford, the British found the idea of a 'Nigerian' nation 'dangerous,' and thus encouraged multiculturalism as a means of 'divide and rule.' In the earliest decades of the $20^{\text {th }}$ century, multiculturalism was approached by the British in contradistinction to unity. Stated Clifford:

Assuming...that the impossible were feasible - that this collection of selfcontained and mutually independent Native States, separated from one another, as many of them are, by great distances, by differences of history and traditions, and by ethnological, racial, tribal, political, social and religious barriers, were indeed capable of being welded into a single homogeneous nation - a deadly blow would thereby be struck at the very root of national self-government in Nigeria, which secures to each separate people the right to maintain its identity, its individuality and its nationality, its chosen form of government; and the peculiar political and social institutions which have been evolved for it by wisdom and by the accumulated experience of generations of its forebears (Coleman 1958: 194).

Evidently, Clifford did not accept the 'premise of multiculturalism as a principle [of] respect for the pluralism of cultures' (Sniderman and Hagendoorn 2007: xi). What he articulated was fear of such pluralism as the basis for constructing mutual peace, justice and equity among cultures.

In his Background to Nigerian Nationalism (1958: 45-46), James Coleman captures this attitude, which didn't change significantly as Nigeria approached independence:

The artificiality of Nigeria's boundaries and the sharp cultural differences among its peoples point to the fact that Nigeria is a British creation and the concept of a Nigerian nation is the result of the British presence.... The present unity of Nigeria, as well as its disunity, is in part a reflection of the form and character of the common government - the British superstructure - and the changes it has undergone since $1900 \ldots$...

Such was the depth of the differences between the administration of the two hitherto separate entities (northern and southern protectorates) that 'the different policies and conceptions of colonial administration which evolved in each of the two protectorates during the fourteen years of their separate existence continued to dominate official thought and action' (ibid: 48). The bureaucracies in the two areas operated separately, while the colonial officials in the two protectorates also represented the two areas as if they were representatives of two different countries.

However, the process that led to the bi-furcation of the north and the south and the further bifurcation of the south into Western and Eastern regions, for the most part, glossed over the several minority groups in these three regions, thus imposing the three largest majority groups, Hausa-Fulani (north), Igbo (east) and Yoruba (west) over more than three hundred minority groups. Yet, by the late 1940s and 1950s, it became apparent that 'ethnicity, and the need to accommodate disparate ethnic nations within the proposed Nigerian independent territory, would pose a sizeable challenge.... [Because the] ethnic minorities were not to be pacified by the usual rhetoric and promises' (Vickers 2010: 3). Given the agitations of the minority groups as Nigeria approached independence - as evident in the 1957 Conference on Nigeria's (Independence) 
Constitution that was held at Lancaster House, London - a Minorities Commission was set up by the British government.

Despite this, before, and even a few years after the creation, in 1963, of the first minority region in Nigeria, the Mid-West Region, the struggle for multiculturalism in Nigeria was largely defined by the tripartite arrangement involving the original three regions, that is, Northern Protectorate and the Western (including the Lagos colony) and Eastern sections of the Southern Protectorate. This rendered 'cultural minorities vulnerable to significant injustice at the hands of the majority, while exacerbating ethnocultural conflict' (Kymlikca 1995: 5). Yet, the hierarchical subdivision of the country during colonial rule into provinces, and districts or divisions, which were supposedly based on 'territorial boundaries of indigenous political units' (Coleman 1958: 48), encouraged these provinces and districts - in which the minority groups were the majority to 'become the focus of a new loyalty and thus... [progress] from the status of an artificial administrative unit to that of a political unit possessed of its own individuality' (ibid).

These two factors - indirect rule and hierarchical subdivision of the country during colonial rule - as Nigeria moved towards independence particularly in the 1950s when different regions of the country fought for and gained a measure of autonomy, ensured that, to use Mamdani's (1996: 298-299) words, "participatory forms ("empowerment") that stress[ed] the autonomy of a bounded group - only to undermine any possibility of an alliance-building majority-based representation,' eventually justified and strengthened 'the most undemocratic forms of central power' (ibid). In the context of the British government's attempt to develop Nigeria into a unitary state, which Awolowo (1947: 47) dismissed as 'patently impossible,' multiculturalism, thus, became a big challenge for the emergent country.

Awolowo had contended in his famous 1947 book, Path to Nigerian Freedom, that 'Nigeria is not a nation [but] a mere geographical expression' (ibid), a sentiment which Margery Perham (1947: 14), the Oxford historian of the British empire, shared, when she noted in her foreword to Awolowo's book that 'There is at present...no Nigeria but the one traced on the map by Britain and held together in a state-system maintained by this country [Britain].' Perham added that, '(i)f Mr. Awolowo is right, as I believe he is, that in face of the deep divisions of race, culture and religion in Nigeria, political advance through natural groups and regions is the only way to a wider unity, then Britain may for long be required to provide the framework which holds three groups together until they are able to fuse into unity or federation' (ibid).

One of the most salient controversies in this era, therefore, was whether the best system by which 'the main groups [could] come together at the centre to pool and share their traditions and resources' (ibid) was a federal or a unitary system. Thus, in the decolonisation period, the colonial government and the representatives of the Nigerian groups confronted the question of how to protect and preserve multiculturalism within the independent nation-state.

Multiculturalism can be understood in the Nigerian context as a strategy for the political management or protection of the country's multi-ethnic reality (including the imbrication of this with religious differences especially along ethno-regional lines. It also connotes, as evident in many parts of Africa, what Tariq Modood calls 'political accommodation of minorities' (2007: 5). However, the politics of minoritization in Nigeria is politically salient and thus more regularly expressed in the language of maginalization. Thus, minoritization or marginalization is not limited to ethno-linguistic groups which are politically categorized as minorities, it also involves majority groups which imagined themselves, at one point or the other, to have been, or likely to be, marginalized by the other groups. Furthermore, in Nigeria, multiculturalism is not 
only a response to the politics of identity, it is also critical for the politics of resource distribution and access to political power. Additionally, it can be argued that, in the decolonization and immediate post-independence eras, multiculturalism in principle constituted a rhetoric for preventing the breaking up of the country in the light of the threats or attempts by the three regions of the country to secede at different points.

\section{'When Ways of Life Collide'}

Nigeria is one of the stark examples of "what actually happens when issues of group identity are made the focal point of public attention and political argument in the inevitably rough and ready tumble of real politics' (Sniderma and Hagendoorn 2007: xi) in Africa.

The leaders of the northern region on the one hand, and the leaders of the southern region on the other hand, approached the question of when Nigeria would achieve self-government as one that reflected the 'essential' difference between the two hitherto separate territories. In one strand of what I describe as call the cultural discourse of duality which in colonial Nigeria constituted the backdrop to this difference, northerners, generally, were constructed by their leaders and the British colonial officers as 'restrained', 'dignified', 'cultured,' 'respectable,' and 'respectful' of their British overlords; while southerners were constructed by the same people (northern leaders and the British) as 'rash,' or 'impatient,' 'aggressive,' 'disdainful of the "backward" north,' 'eager to dominate the north,' and 'disrespectful' of their British overlords. In the alternative strand of the cultural discourse of duality, southerners, generally, were constructed by their own leaders as 'progressive,' or 'radical,' 'freedom loving,' 'forwardlooking,' 'modernity-embracing,' 'enlightened,' 'developed' (comparatively) and opposed to perpetual foreign domination; while northerners were constructed by the southerners as 'backward,' 'conservative,' 'feudal,' 'unenlightened stooges of imperialists,' and opposed to the unity and independence of Nigeria. ${ }^{7}$

No doubt the reality was far more complex than the simplistic attitudes and discourses alternatively deployed by these leaders, their supporters, the newspaper press and the British colonial officers. Yet, this cultural discourse of duality was at the center of the question of multiculturalism in colonial Nigeria, reflecting both the dimensions and the limitations of multiculturalism in late colonial era. As the pressure for self-government became more intense after the end of World War II, with the British Empire expressing willingness to bring its former colonial possessions into the British Commonwealth, the challenge of managing multiple identities in these colonial possessions moving toward independence became a central concern. However, managing the multiple identities could not be done in a vacuum. Therefore, the pressure for self-rule also quickened the pace of constitutional advance (Sklar 1963: 87), given that the constitutional or legal process was the best guarantor of the right to difference. The pace of constitutional development in the colonies, in turn, stimulated the development of political parties (ibid), given that the power to protect difference and identities at the period could not also be acquired in a vacuum - particularly, where cultural, ethnic, communal and other identity groups were insufficiently powerful to dictate the sharing of political power.

In the case of Nigeria, the question indirect rule system which promoted decentralization, provided a contradictory political legacy in relation to the emergent need for centralized parliamentary democracy. While British imperial interests, alongside conservative chiefs and traditionalists favored the continued development of the native authority system, most Nigerian nationalists favored a move towards parliamentary institutions (Coleman 1958: 273). However, 
even among those who favored the latter, there were deep disagreements regarding the details and the pace.

Given the existing unitarist structure in Nigeria imposed by the British ${ }^{8}$, the Richards Constitution of 1945 was the first constitutional attempt towards federalism. The concept of regionalism was the most important and acceptable feature of this constitution (Coleman 1968: 276). This was a compromise between regional separatists, who wanted three separate states, and the strong federalists, who wanted a central parliament (ibid). For Sir Arthur Richards, the Governor-General of Colonial Nigeria, the 'embryonic, quasi-federal structure' created by the 1945 constitution was a 'practical means' of ensuring two major objectives. It had the potential to promote national unity in Nigeria, and at the same time, accommodate diversity within unity (ibid). Responding to those who argued that regionalism would promote separatism, Sir Bernard Bourdillon, Richards predecessor, stated that 'in fact, this measure represents not the division of one unit into three, but the beginning of the fusion of innumerable small units into three and from these three into one' (ibid: 276-277). Despite the objections of the three regions to some parts of this constitution, all the major parties and the leaders of the three regions, particularly the northern region, applauded the regional arrangement.

Why did all the regional leaders at this point embrace regionalism in the context of multiculturalism? What constituted the historical circumstances which dictated this position in each case and what were the responses? What were the differences in their different approaches to regionalism in relation to multiculturalism and nationalism? I will attempt to answer these questions in the following sections of this chapter.

\section{Multiculturalism: Between Burkean and Jacobin Nationalism}

I have suggested earlier that the constitutive challenge of multiculturalism in Nigeria can be understood and analyzed mainly against the backdrop of the legacy of colonialism, particularly late colonialism - a period during which 'prevailing communal forces reinforced regional networks of power and patronage that dominated political behaviour' (Vaughan 2003: 231). By bringing together two separate territories and governing it for a few decades as two or three separate territories with two or three 'distinct' cultures, the British, with the ironic collaboration of the leaders of the ethno-regional political parties in the colonial era, created a particular kind of politics in which multiculturalism became a crisis or a problem to be confronted and transcended, rather than an asset to be embraced and managed. Thus, ethnic (in the case of Nigeria, also ethno-regional) self-consciousness produced a situation in which 'relationship among groups was one of ethnic stratification...rather than ethnic coexistence' (Coleman 1958: 129). As Coleman (ibid) correctly noted, '( $t$ )erritories having a pattern of duopoly or a tripolar pattern were, as in all situations of bi- or tripolarity, vulnerable to the delicate balance of their ethnic duality or plurality suddenly giving way to a polarization into total ethnic bloc opposition or rivalry.'

In the light of this, while most of the nationalists paid lip-service to, or indeed desired, national 'unity-in-diversity,' the reality of the prior non-existence of such unity, territorial or political, ensured that no real unity was achieved. This only confirms Emerson's position that '(w)here there is original unity, nationalism serves further to unite; where there is a felt ethnic diversity, nationalism is no cure' (cited in Coleman 1958: 130). It is important, therefore, to understand the different approaches of the major pre- and immediate post-independence ethno- 
regional blocs, political parties and regional leaders to multiculturalism through the lens of the traditions of Jacobin and Burkean forms of nationalism.

Jacobin Nationalism: Azikiwe, NCNC and the Eastern Region,

The National Congress for Nigerian Citizens, under the leadership of Nigerian nationalist, journalist and anti-colonial agitator per excellence, Dr. Nnamdi Azikiwe, an Igbo from Eastern Nigeria, was Nigeria's earliest example of a political party driven by a Jacobin approach to multiculturalism. Although the NCNC was later identified with the Igbo-dominated eastern region of Nigeria, it was founded, as Azikiwe (1961: 163, emphasis added) stated 'in order to unify the various elements of our communities... and to emancipate our nation from the manacles of political bondage.'

The mantra of Jacobin form of nationalism, emerging from the French experience, was 'la nation une et indivisible' (the nation, one and indivisible). Its goal was to combine 'the heritage of the different regions... in one national heritage; producing a republican monocultural universalism from disparity' (Van de Putte 1994: 114). As Furniss (2000: 138) would have described it, NCNC's form of nationalism was a 'modernizing nationalism that sought to replace local identities and differences with a homogenized national politics and culture.'

Among the nationalist leaders, Azikiwe, using the NCNC and his chain of newspapers, particularly the West African Pilot, was the most vociferous about creating a nation that sidestepped or transcended the existing 'tribal' (ethnic) groups and emergent ethno-regional arrangements. Despite Azikiwe's rather ironic position as the president of the Ibo State Union, and his statement at the 1949 conference of the union that '... it would appear that the God of Africa has specially created the Ibo [Igbo] nation to lead the children of Africa from the bondage of the ages' (Coleman 1958: 347), he and his chain newspapers were opposed to the building of what the Pilot called 'ethnic shrines.' Azikiwe, NCNC and the Pilot insisted that they were championing an 'integral nationalism' while offering themselves 'as the protector of morally superior national values and interests' - to use the words of Van de Putte (1994: 14). Azikiwe argued that the recognition and validation of ethnic particularities were antithetical to the emergence of a strong and united Nigeria. He argued further that, despite its multicultural heritage, Nigeria ought to become a melting pot rather than a potpourri. This position was adopted by many Igbo leaders and intellectuals in late colonial Nigeria and thus became not only the NCNC's position, but also the 'Igbo position,' given the preponderance of Igbo support for the party and its leader. The Pilot dismissed any contrary position as 'pakistanization,' a metaphor for the feared balkanization of Nigeria (along Indian/Pakistani lines) by those championing federalism.

Interesting enough, even though a federal system constitutes a fundamental recognition of difference and diversity, a recognition that allows complex societies to manage their common affairs at a central level while also guaranteeing the independence of constituent units in the management of their local affairs (Wheare 1963: 19), Azikiwe, at some point, supported the adoption of a federal system for Nigeria. Between 1943 and 1948, he advocated that Nigeria be divided into eight protectorates under a federal colony. Some of these protectorates roughly coincided with ethnic boundaries. In 1948, the NCNC in its Freedom Charter, also advocated a federal system based strictly upon ethnic units (Coleman 1958: 347). This was a clear acknowledgement of the country's multiculturalism. 
However, in 1951, Azikiwe and the NCNC leaders suddenly changed their minds. The party stated that 'in view of recent divisionist tendencies in the country and to accelerate the attainment of our goal for a united Nigeria, a unitary form of government with the acceptance of the principle of constituencies will be better for Nigeria ...' (Coleman 1958: 324 emphasis added). The excuse for the new position was that the colonial government 'and anti-NCNC Nigerians were using federalism as a cloak for dismembering Nigeria' (ibid: 348, emphasis added). As Coleman correctly notes, other, perhaps more critical, reasons for the change were the emergence of a strong and well-organized political party in the Western Region, the Action Group (AG), and the structure and organization of the 1951 Macpherson Constitution - which succeeded the Richards Constitution. Based on a more democratic process than was followed in the adoption of the Richard's Constitution, the Legislative Council in Lagos appointed a select committee to consider the question of the status of the national capital, Lagos. Azikiwe (representing the NCNC) as a member of the committee, wrote a minority report in which he objected to the tripartite division of the country into regions, or what he called 'tri-sected Pakistanized country' (Azikiwe 1961: 173) He argued for 'the division of the country along the main ethnic and/or linguistic groups [i.e., ten] in order to enable each group to exercise local and cultural autonomy' (quoted in Coleman 1958: 348). The position of Azikiwe and NCNC may seem inconsistent except one understands that the emergence of a Yoruba-dominated AG in the Western Region (which at some point included Lagos) where the NCNC had held sway meant that the party could face the possibility of defeat in the Regional House of Assembly under a federal system. Indeed, the fears of the NCNC were confirmed later in the 1951 elections. ${ }^{9}$

Azikiwe and the NCNC members insisted that their party - unlike the others, particularly the AG, and later the Northern People's Congress (NPC) - was championing the building of a 'homogeneous' nation. It was not again until 1954 that Azikiwe and the NCNC accepted the federal system in the march towards Nigeria's independence. However, it was obvious to the other parties and regions of Nigeria, that this was a grudging acceptance of the reality, resulting from the rigidity of the stance of the Action Group/Western Region and the NPC/Northern Region. Indeed, Azikiwe and the NCNC never abandoned their position that regionalism and ethno-regional parties were manifestations of 'division' rather than diversity. In the rhetoric and writings of Azikiwe and the spokesman of the NCNC, multiculturalism was portrayed as a problem for any emerging African nation-state. What the others saw as the refusal of Azikiwe and the NCNC/Eastern Region to accept the reality of Nigeria's multicultural composition by canvassing for a unitary system was linked to fears of what the other two major ethno-regional groups described as an attempt at 'Ibo [Igbo] domination' of Nigeria. This continued to hover above the political system and also defined the relationship between the three major groups - and partly provoked to the counter-coup led by northern soldiers against the Igbo-led military regime in July 1966 and, eventually, the Nigerian Civil War (1967-1970).

\section{Burkean Nationalism: Awolowo, AG and the Western Region}

In contrast to the Jacobin form of nationalism championed by Azikiwe and the NCNC, the Chief Obafemi Awolowo and Action Group articulated a Burkean notion of nationalism, which fitted Nigeria's multicultural nature, even though it had the potential to acerbate ethnic tension and deepen existing conflicts, particularly between the two major southern ethnic groups, the Igbo and the Yoruba. 
In arguing against French 'revolutionary nationalism...whose centrist and potentially totalitarian tendencies he represents as destructive of the sense of nation...' (Furniss 2000: 136), Burke supported '(s)uch divisions of our country as have been formed by habit, and not by a sudden jerk of authority,' adding that ' $(\mathrm{t})$ he love to the whole is not extinguished by this subordinate partiality...' (quoted in ibid: 138). For Burke, local attachments, identifications, and loyalties are not barriers to national ones, but only prepare the mind for larger loyalty. In advocating for a hierarchy of loyalties, 'each supreme in its own sphere' (Hayes 1931: 93), Burke pointed to the form of multicultural nationalism that Awolowo and AG advocated for Nigeria.

Unlike the NCNC members and its leader, who emphasized their pan-Nigerian identity, Coleman (1958: 351) argues that, 'more in the tradition of Burke, Awolowo had always been a Yoruba nationalist first and a pan-Nigerian nationalist second.' Therefore, from 'the beginning...there was a fundamental difference in attitude regarding the ends toward which the nationalist movement should be directed' (ibid). When the Egbe Omo Oduduwa (Society for the Descendants of Oduduwa) was formed as a cultural organization for the Yoruba, first in London in 1945 and later in Nigeria in 1948, the group advertised two of its objectives to include the acceleration of 'the emergence of a virile modernized and efficient Yoruba state with its one individuality within the Federal State of Nigeria,' while striving 'earnestly to cooperate with existing ethnic and regional associations and such as may exist thereafter, in matters of common interest to all Nigerians, so as to thereby attain to unity in federation' (Arifola 2001: 107-108; Adebanwi 2014: 53).

The Egbe later became the basis of the creation of a political party, Action Group, devoted to capturing power in the Western Region in the decolonization period. The party, led by Awolowo, resolved that 'under the circumstances then prevailing in [late colonial] Nigeria the only certain avenue to power was a regional political party' (Coleman 1958: 350). Thus, one of its most important campaign strategies for mobilizing support in the region was opposition to Azikiwe, the NCNC and the threat of 'Igbo domination' under the unitary system.

In his autobiography, Awolowo states that he wanted to rebuild Yorubaland to ensure that every cultural group would have a pride of place in a multicultural Nigeria. This attitude and the activities geared toward validating it were dismissed by the NCNC and Azikiwe's Pilot as a process of the 'pakistanization' of Nigeria. The Pilot (July 19 1952: 2) regarded AG's version of multiculturalism as a 'determination to remain difficult to Nigerian unity' through the imposition of 'the evils of regionalization.' The AG was described as a 'parochial party,' pursuing 'parochial nationalism' and engaging in 'tribalistic demarcation of the country' (Pilot October 1, 1952: 2) as opposed to the NCNC which had a 'national policy' (Pilot, July 19 1952: 2).

In Path to Nigerian Freedom, Awolowo emphatically rejected the unitary system. He argued that '(s)ince the amalgamation, all the efforts of the British Government have been devoted to developing the country into a unitary state... This is patently impossible...' He added that while the existing three regions were 'designed for administrative convenience, a truly federal system would require boundary readjustments to ensure that each group, however small, is entitled to the same treatment as any other group, however large... Opportunity must be afforded to each to evolve its own peculiar political institution' (Coleman 1958: 324).

In the end, by leveraging Yoruba cultural nationalism, Awolowo, the Egbe Omo Oduduwa and the Action Group, not only contested the Jacobin 'revolutionary nationalism' preached by Azikiwe, and the NCNC, but successfully promoted a Burkean recognition of a 
hierarchy of loyalties in a multicultural federal state in which each component part of the federation, at least notionally, was supreme in its own sphere. However, Awolowo and the AG did not succeed in making ethno-linguistic units the component parts of a multicultural Nigerian state. The units remained three (later four) multi-ethnic regions until 1967 when they became states.

\section{Neo-Burkean Nationalism: Bello, NPC and the Northern Region}

Given its delayed and reluctant encounter with European modernity, the Northern Protectorate, the huge and conservative laager constructed around the Fulani-led Caliphate that emerged from the 1804 jihad, had an understandably different attitude to the struggle for national unity as Nigeria moved towards independence. Apart from the factors already mentioned above, several other factors also provided the context for the specific approach that the northern region, its' dominant party, the Northern People's Congress (NPC), as well as its preeminent leader, Sir Ahmadu Bello, adopted in responding to the challenges of national unity after the two protectorates were amalgamated to form a single British colony (see Coleman 1958; Whitaker 1970; Vaughan 2013).

These included the insulation of the northern protectorate from Christian missionary conversion and Enlightenment campaign - including expansion of opportunities for Western education - which strengthened existing differences and ratified it strongly along ethno-regional lines; the shift in the production of cash crops for export (Coleman 1958: 353); and the expansion and consolidation of Islamic influence and dominance based on the numerical strength of the combined ethnicities of Hausa and Fulani (Hausa-Fulani) in much of the northern region. The British colonial officers in the Northern Protectorate too were instrumental in this process. Such was their commitment to making the north distinct from the south, despite the amalgamation, that between 1923 and 1947, the northern leaders were not represented in the central Nigerian Legislative Council in Lagos, the capital of colonial Nigeria. Therefore, the north lagged behind the south in engaging with modern democratic institutions and practices. These led to fears of southern domination, the policy of 'northernization' in the late colonial and early postcolonial eras, the north's initial opposition to Nigeria's independence in the mid-1950s and a unique outlook on multiculturalism which admitted of a different standpoint for the multicultural region from the one adopted for the whole of Nigeria. Thus, while northern leaders, led by Ahmadu Bello, were eager to unify the northern region and transcend cultural, ethnic and religious differences within the region, particularly among the region's many minority groups, ${ }^{10}$ they insisted that Nigeria was a multicultural polity, but one in which the northern region must be recognized as a single cultural whole as well as political community. This was despite the fact that 'the Northern Region is not a cultural or a historical unit' (ibid: 354). Indeed, 'from a tribal standpoint,' as Coleman correctly concluded, 'the north is far more heterogeneous than the south. [Though the] integrative bonds of Islam and the Fulani Empire, however, have given a large part of the north a certain feeling of identity' (ibid).

This background is important because the reality in the north, or the way in which that reality was understood by the leaders of the NPC in relation to the rest of Nigeria, dictated their approach to multiculturalism, particularly in response to the most suitable political system for Nigeria as the country approached independence in the late 1940s and the 1950s.

However, even though both Bello and Awolowo preached Burkean nationalism, the Bello -NPC's articulation of why and how federalism was the most suitable political system for 
'understanding' and protecting differences was qualitatively different from the Awolowo- AG's. It emerged from a different reading of history and comparative experience. While the AGAwolowo position emerged from a deliberate and elaborate analysis of both local and global experiences of multiculturalism and was influenced by desire for power in the emerging political configuration, the Bello-NPC position was influenced largely by both fears of southern domination in a unitary system and the associated disagreement with the southern leaders over a proposal favored by the AG and NCNC that Nigeria should be granted independence in 1956. The leaders of the northern region felt that the region was not ready, and thus risked the substitution of British colonialism for internal (Southern Nigerian) 'colonialism'. The northern leaders' position, followed a pattern adopted by groups which felt disadvantaged by the move towards independence as famously noted by Donald Horowitz (1985: 4). Such groups often attempt 'to slow down the march to independence or to gain special concessions.'

While Bello and NPC focused on and campaigned for regional multiculturalism, that is, the recognition of each region as a cultural unit (as well as the primary form of affiliation/nationalism) within the federation of Nigeria, Awolowo and the AG favoured ethnolinguistic multiculturalism, ${ }^{11}$ that is, a federation of nationalities, with ethnic nationality as the primary form of affiliation/nationalism. Awolowo (1947: 48) emphasized the country's multiculturalism, noting that groups called 'tribes' were actually 'nations' and mentions ten of such groups recorded during the 1931 census including the Hausa, Ibo (Igbo), Yoruba, Fulani, Kanuri, Ibiobio, Munshi or Tiv, Edo, Nupe and Ijaw. He makes the additional point that given that, there 'is as much difference between them [the 'nations'] as there is between Germans, English, Russians, and Turks,' the fact that 'they have a common overlord [the British] does not destroy this fundamental difference.' He elaborates on this by stating that the languages of these groups 'differ... Their cultural backgrounds and social outlooks differ widely; and their indigenous political institutions have little in common. Their present stages of development vary... It is evident from the experiences of other nations that incompatibilities such as we have enumerated are barriers which cannot be overcome by glossing over them. They are real, not imaginary, obstacles' (ibid: 48-49). Bello shared this position only to the extent that the differences were limited to external regional differences, not differences internal to the region, particularly, his own northern region. Thus, for Bello, the northern region was a cultural unit, while for Awolowo, the ethno-linguistic group ought to be the cultural unit. Therefore, for Awolowo, the Hausa-Fulani (ethno-cultural group) would be a federating unit rather than the north (region), as favoured by Bello.

After the crisis over the date of independence, as Bello (1962: 136) notes in his autobiography, the northern region decided to 'take a modified line'. He elaborated on this by stating that the northern region 'must aim at a looser structure for Nigeria while preserving its general pattern - a structure which would give the regions the greatest possible freedom of movement and action; a structure which would reduce the powers of the Centre to the absolute minimum and yet retain sufficient national unity for practical and international purposes' (ibid). He advocated for a 'federal principle' in which 'what happened in Lagos [the federal capital, would not be] of great consequences...in the north' (ibid: 227).

Eventually, the federal system adopted by Nigeria at independence was largely a compromise between the Bello-NPC-Northern Region and Awolowo-AG-Western Region positions. As one of the earliest scholars of Nigerian federalism notes, these two were the most vociferous in 'repeating that they would not be dominated by other areas of tribal groups' 
(Mackintosh 1962: 223). However, even while notionally encouraging multiculturalism, structurally, the federal system adopted in Nigeria before independence leveraged multiculturalism while limiting it largely to ethno-regional diffrences. This became a problem in the post-independence era as minority groups in the three regions demanded greater recognition of their differences from the three big ethnic groups (see, Osaghae 1986, 1991, 1998; Suberu 2001, 2009; for the background to this, see, Vickers 2010).

\section{The Limits of Regionalist Federalism}

Some scholars have argued that one of the primary steps that must be taken in achieving a 'fuller conception of multiculturalism' in the quest to 'deal with diversity', is to break down 'the false opposition between unity and difference, between solidarity and diversity, or ... between universalism and particularism' (Hartmann and Gerteis 2005: 221). Against this backdrop, they propose that multiculturalism should be approached in multiple ways as (i) 'a critical-theoretical project,' (ii) 'an exercise in cultivating new conceptions of solidarity in the context of dealing with the realities of pervasive and increasing diversity,' (iii) a response - or a set of responses to diversity that seeks to articulate the social conditions under which difference can be incorporated ... and order achieved from diversity' (ibid: 222). Hartmann and Gerteis argue for bringing different approaches into a 'productive tension with each other' in order to reconcile different 'visions of difference.'

The Nigerian case examined here illustrates the fundamental challenges faced in the attempt to reconcile 'visions of [multicultural] difference' as well as the problem on constructing a workable political system to accommodate and address the difference. Even though the federalists won the debate in the late colonial era with Nigeria becoming a federation at independence, it was specifically the regionalist version of multiculturalism that triumphed as the struggle by minority groups for recognition beyond tokenism were largely ignored in the tripartite arrangement - Hausa-Fulani-dominated Northern Region, Igbo-dominated Eastern Region and Yoruba-dominated Western Region - that was established. However, the attempt to return the country to a unitary system after the January 1966 coup led to disastrous consequences including the 30-month long civil war in which more than one million people died. Yet, while multiculturalism is not antithetical in principle to nation-building, it has served contradictory purposes in the Nigerian federation. Even though the multicultural nature of the country is not always respected and honoured, the recognition of the multicultural nature of the federation and the limitations and responsibilities this imposes on political leaders have, on the one hand, prevented Nigeria from fully achieving its potentials as a rich and powerful nation in the developing world, and, on the other hand, averted the total disintegration of the country. Also, while there is a popular view in Nigeria that the recognition of the country's multiculturalism has thwarted national integration, there is also a conflicting popular recognition of the fact that even the existing instrumental recognition of multiculturalism helps in the unending struggle to ensure that all the major cultures are given a measure of, it not, equal space and value.

Shortly before the civil war, the political elite seemed to have reached a consensus regarding the wisdom of some of the country's leaders who earlier advocated for multiple territorial division of the country beyond the three regions (later four in 1963) inherited from colonial rule. Even though the 12 states which emerged from the four regions before the outbreak of civil war did not exactly match the ethno-linguistic divisions proposed in the 1940s and 1950s - apart from the fact that it was specifically geared towards discouraging the minorities in the old 
Eastern Region from supporting the Igbo-led attempted secession - the creation of states pointed to greater recognition of the multicultural reality of the Nigerian federation. It was evident, as Coleman had predicted in his 1958 book, that Nigeria could not survive on the basis of exclusive regional multiculturalism with the structural region-based federalism that was adopted at independence.

The end of the civil war (1967-1970) witnessed greater recognition, and accommodation, even if not totally satisfactory, of minority interests and a greater embrace of Nigeria multicultural realities. This was so despite the fact that structural unitarism was practiced in the name of federalism by a succession of the mis-named Federal Military Governments (1966$1979 ; 1983-1999)$. However, in spite of the structural unitary system which subsisted for many years in Nigeria in the guise of a federal system, the division of the country into more and more states (three regions, four regions, 12 states, 19 states, 21 states, 30 states, and now 36 states) has to some extent decreased tension regarding the non-recognition of difference. Nonetheless, this solution constitutes what Eghosa Osaghae calls a 'broad catch-all' policy. ${ }^{12}$ Still, the fundamental questions regarding the terms of national relations remain critical and in 'productive tension,' in Nigeria, ${ }^{13}$ particularly because bi- or tri-polarity still largely determines the nature of power sharing at the highest level of national relations. This has since been further divided administratively into six zones: north-west, north-east, north-central, south-east, south-west, and south-south.

\section{Conclusion}

The Nigerian experience, as reflected in the debates on the best political system in the late colonial era, points to the failure of assimilationism in multi-ethnic polities in Africa. The attempt to deny the mediating role of ethnic and cultural groups and 'deal with difference by removing it' (Hartman and Gerteis 2005: 226) championed by the Azikiwe-NCNC did not succeed. What triumphed in the late colonial era is what Hartman and Gerteis (2005) have described as 'fragmented pluralism,' which is the opposite of assimilationism. This was what Bello-NPC and Awolowo-AG supported and practiced. Fragmented pluralism is based on 'strong preexisting group boundaries,' with a strong emphasis on the maintenance of 'distinctive group cultures' (ibid: 230). The orientation to diversity in this model is 'closest to the standard definition of multiculturalism.' In late colonial Nigeria, the ethno-regional group was regarded as the valid group. In this sense, because the three (later four) regions and even the ethnic groups subsumed under them were also based on what Durkheim described as 'mechanical solidarity,' 'group boundaries [were] policed in the way that social boundaries [would have been] in assimilationism' (ibid).

Yet, while fragmented pluralism was triumphant in the pre- and immediate postindependence period, what the pluralists actually preached in the emphasis on 'understanding difference', as Bello articulated it, was a 'better' form of pluralism, that is, 'interactive pluralism.' I suggest that this is what the Burkean notion of nationalism actually aims for. It is what Nigeria's postcolonial leaders, despite their actions, have also publicly valorised. As explained by Hartman and Gerteis (ibid), interactive pluralism emphasizes 'mutual recognition and respect of difference,' even while insisting on 'the importance of the [ethno-regional] groups as primary basis for association in society.' However, because the 'groups in interaction' was based on mutual fears and negative evaluations of the other groups' assumed intention, Nigerian multiculturalism in the late colonial and early post-colonial era was fragmented rather than 
interactive. Though much hope was expressed for an emergent unity in the future which would honour and respect multiculturalism, token efforts were undertaken in terms of 'substantive commitments' to produce sustainable democratic federalism. However, despite the fact that federalism has survived without being entrenched in post-independence Nigeria (cf. Suberu 2009: 67), the survival has been sufficient in keeping the multicultural state together, even if the nature and ideal of multiculturalism continues to be contested.

\section{References}

Abubakar, Abdullahi Tasiu (2014). 'Analysis: What did Nigeria's National Conference achieve?' BBC, August 24. http://www.bbc.com/news/world-africa-28929532 (Accessed November 10, 2016).

Adebanwi, Wale. 2014. Yoruba Elites and Ethnic Politics in Nigeria: Obafemi Awolowo and Corporate Agency. New York: Cambridge University Press.

Agbaje, Adigun and Adebanwi, Wale. 2003. 'The Political Economy of the Problems of Nigerian Statehood.' In Richard .A. Olaniyan (ed.) The Amalgamation and Its Enemies (An Interpretive History of Modern Nigeria), Obafemi Awolowo University Press, IleIfe.

Arifalo, S. O. 2001. The Egbe Omo Oduduwa: A Study in Ethnic and Cultural Nationalism, 1945-1965. Akure: Stebak Books and Publishers.

Bayat, Adef. (2009) Life as Politics. Stanford: Stanford University Press.

Awolowo, Obafemi. 1947. Path to Nigerian Freedom. London: Faber and Faber Ltd.

Awolowo, Obafemi. 1960. Awo: An Autobiography. Cambridge: Cambridge University Press.

Awolowo, Obafemi. 1960. Awo: The Autobiography of Chief Obafemi Awolowo. Cambridge: Cambridge University Press.

Azikiwe, Nnamdi. 1961. Zik: A Selection from the Speeches of Nnamdi Azikiwe. Cambridge: Cambridge University Press.

Bekker, Simon and Anne Leidé. 2003. "Is Multiculturalism a Workable Policy in South Africa?" International Journal on Multicultural Societies, Vol. 5, No. 2: 121 -136.

Bello, Ahmadu. 1962. My Life. Cambridge: Cambridge University Press.

Coleman, James S. 1958. Nigeria: Background to Nationalism. Berkeley and Los Angeles: The University of California Press.

Coleman, James S. 1994. Nationalism and Development in Africa: Selected Essays. Richard L. Sklar (ed.) Berkeley: University of California Press.

Crowder, George. 2013. Theories of Multiculturalism: An Introduction. Cambridge, UK: Polity Press.

Dudley, B. J. (1966). 'Federalism and the Balance of Political power in Nigeria.' Journal of Commonwealth Political Studies, 4 (1) 16-29.

Furniss, Tom. 2000. 'Cementing the Nation: Burke's Reflections on Nationalism and National Identity.' In John Whale (ed.) Edmund Burke's Reflections on the Revolution in France: New Interdisciplinary Essays. Manchester: Manchester University Press. pp. 115-144.

Goldberg, David Theo. 1994. 'Introduction.' In David Theo Goldberg (ed.) Multiculturalism: A Critical Reader. Malden, Mass.: Blackwell Publishers.

Gutmann, Amy. 1993. 'The Challenge of Multiculturalism in Political Ethics', Philosophy \& Public Affairs, Vol. 22, No. 3: 171-206. 
Hale, Charles R. 2002. 'Does Multiculturalism Menace? Governance, Cultural Rights and the Politics of Identity in Guatemala,' Journal of Latin American Studies, 34: 485-524.

Hartmann, Douglas and Joseph Gerteis. 2005. 'Dealing With Diversity: Mapping Multiculturalism in Sociological Terms,' Sociological Theory, Vol. No. 2: 218-240.

Hayes, Carlton. 1931. The Historical Evolution of Modern Nationalism. New York: Macmillan.

Horowitz, D. L. (1985). Ethnic Groups in Conflict. Berkeley: University of California Press.

Horowitz, D. L. (1991). A Democratic South Africa? Constitutional Engineering in a Divided Society. Berkeley: University of California Press.

Elaigwu, Isawa. 2010. 'Federal Systems not New to Africa.' Forum of Federations. http://www.forumfed.org/en/products/magazine/vol10_num1/federal-systems-notnew.php. (Accessed July 31, 2014).

Kirk-Greene, A. H. A. 1969. Lugard and the Amalgamation of Nigeria: A Documentary Record. London: Frank Cass.

Kymlicka, Will. 1995. Multicultural Citizenship: A Liberal Theory of Minority Rights. Oxford: Oxford University Press.s

Kymlicka, Will. 2001. Politics in the Vernacular: Nationalism, Multiculturalism, and Citizenship. Oxford: Oxford University Press.

Kymlicka, Will. 2007. Multicultural Odysseys: Navigating the New International Politics of Diversity. Oxford: Oxford University Press.

Kymlicka, Will. 2012. Multiculturalism: Success, Failure, and the Future. Washington, DC: Migration Policy Institute.

Lugard, F. D. 1922. Dual Mandate in British Tropical Africa. Edinburgh and London: William Blackwood and Sons.

Mackintosh, John P. 1962. "Federalism in Nigeria." Political Studies, Vol. 10, Iss. 3: 223-247.

Mamdani, Mahmood. Citizen and Subject: Contemporary Africa and the Legacy of Late Colonialism. Princeton, NJ: Princeton University Press.

Modood, Tariq. 2007. Multiculturalism. Cambridge: Polity Press.

Omoruyi, Omo. 1999. The Tale of June 12: The Betrayal of the Democratic Rights of Nigerians (1993). London: Press Alliance Network Ltd.

Osaghae, Eghosa E. 1986. 'Federalism, Local Politics and Ethnicity in Nigeria: Do Ethnic Minorities Still Exist in Nigeria?' The Journal of Commonwealth \& Comparative Politics, Vol. 24, Iss. 2: 151-168.

Osaghae, Eghosa E. 1991. 'Ethnic Minorities and Federalism in Nigeria.' African Affairs, Vol. 90, No, 359: 237-258.

Osaghae, Eghosa E. 1998. 'Managing Multiple Minority Problems in a Divided Society: The Nigerian Experience.' The Journal of Modern African Studies, 36, 1: 1-24.

Paden, John, N. 1986. Ahmadu Bello. Sardauna of Sokoto: Values and Leadership in Nigeria. Zaria: Hudahuda Publishing Company.

Parekh, Bhikhu. 2002. Rethinking Multiculturalism: Cultural Diversity and Political Theory. Cambridge, Mass: Harvard University Press.

Perham, Margery. 1947. 'Foreword.' In Obafemi Awolowo, Path to Nigerian Freedom. London: Faber and Faber Ltd.

Philip, Anne. 2007. Multiculturalism Without Culture. Princeton, NJ: Princeton University Press.

Sklar, Richard L. 1963. Nigerian Political Parties: Power in an Emergent African Nation. Princeton, NJ: Princeton University Press. 
Sniderman, Paul M. and A. Hagendoorn. 2007. When Ways of Life Collide: Multiculturalism and Its Discontents in the Netherlands. Princeton, N.J.: University of Princeton Press.

Soudien, Crain. 1994. "Dealing With Race: Laying Down Patterns for Multiculturalism in South Africa." Interchange, Vol. 25/3: 281-294.

Suberu, Rotimi. 2001. Federalism and Ethnic Conflict in Nigeria. Washington D. C.: United States Institute of Peace.

Suberu, Rotimi. 2009. 'Federalism in Africa: The Nigerian Experience in Comparative Perspective.' Ethnopolitics, Vol. 8(1): 67-86.

Taylor, Charles. 1992. 'The Politics of Recognition.' In Amy Gutmann (ed.), Multiculturalism and the Politics of Recognition. Princeton, NJ: Princeton University Press.

Van de Putte, André. 1994. 'Nationalism and Nation.' Ethical Perspectives, 1: 104-123.

Vaughan, Olufemi. 2013. 'Ethno-Regionalism and the Origins of Federalism in Nigeria.' In Wale Adebanwi and Ebenezer Obadare (eds.) Democracy and Prebendalism in Nigeria: Critical Interpretations. New York: Palgrave Macmillan.

Vickers, Michael. 2012. A Nation Betrayed: Nigeria and the Minorities Commission of 1957. Trenton, NJ: Africa World Press.

Wheare, K. C. 1963. Federal Government. Oxford: Oxford University Press.

Whitaker, C. S. 1970. The Politics of Tradition: Continuity and Change in Northern Nigeria, 1946-1966. Princeton: Princeton University Press.

\section{Newspapers \\ Daily Service \\ Daily Times \\ West African Pilot}

\section{NOTES}

\footnotetext{
${ }^{1}$ For a few exceptions, see Hale, 2002.

${ }^{2}$ Which affirms that 'Though tribe and tongue may differ/In brotherhood [sic] we stand.'

${ }^{3}$ Charles R. Hale (2002) puts the question differently: 'Does multiculturalism menace?' Still, he points to the fact that, even if multiculturalism is not inherently a menace, it has the potential to menace.

${ }^{4}$ Even though Paden (1986: 314) argues that Bello viewed the northern regional community 'as a 'trans-ethnic community,' or a federation within a federation,' in fact, he approached multiculturalism primarily in terms of the differences between the northern region (with majority Muslim population) and the southern region (with majority Christian population).

${ }^{5}$ Nigeria and Ethiopia (since 1995) are the two fully federal systems in Africa. A few others have quasi-federal systems or systems with federal features.

${ }^{6}$ One of the most important factors that also informed this attitude was authoritarianism rule which was prevalent in post-independent Africa.

${ }^{7}$ Strands of these discourses are gleaned from the major accounts by the leaders, their biographers, the classic texts on Nigerian politics and Nigerian newspapers in the 1940s and 1950s. See also The Nation as Grand Narrative: The Nigerian Press and the Politics of Meaning (2016).

${ }^{8}$ British colonial officials who supported the northern region were also fearful of unitary system in Nigeria because the 'educated elements in coastal towns [meaning Lagos and other parts of the south] would become predominant.' See, Coleman, p. 275.

${ }^{9}$ It is important to note that the late Nigerian political scientist, Billy Dudley (1966), offered a different reason for Western and Northern regions' support for federalism: first, the political leaders were 'positively attracted' by the 'Wheare model' of federalism; second was economic reason - tied to rising commodity prices in the 1950s which meant that the Western and Northern regions which benefitted most from this were the strongest advocates of
} 
federalism. While these might have been supporting reasons, I think that the leaders' articulation of their reasons, as examined here, do not support Dudley's conclusion.

10 'Our aim,' says Bello in an address to the people of the northern region, 'is to unify the North and make all tribes living in the Region feel that they are one and the same people. The people of the North are in fact already one....' See, Paden, p. 151, footnote 32.

${ }^{11}$ Azikiwe too in his Political Blueprint of Nigeria (1943) 'envisaged a federal commonwealth of Nigeria made up of eight "protectorates," whose boundaries roughly followed ethnic lines' (Coleman 1958: 324). He later changed his mind.

${ }^{12}$ Osaghae (1998: 19) notes that, "By taking states rather than ethnic groups as the units to be represented and balanced, the federal character principle favored majorities and powerful minorities, as opposed to the ordinary (or ' residual') minorities which were dominated in the states.'

${ }^{13}$ The latter has led in part to the rise of fundamentalist religious groups, such as Boko Haram, seeking to obliterate a multicultural society and establish an Islamic state. 